BNL-113226-2016-JA

\title{
Impact of Multifunctional Bimetallic Materials on Lithium Battery Electrochemistry
}

\author{
Jessica L. Durham, Altug S. Poyraz, Esther S. Takeuchi, \\ Amy C. Marschilok, and Kenneth J. Takeuchi
}

Submitted to Accounts of Chemical Research

November 2016

\author{
Energy and Photon Sciences Directorate \\ Brookhaven National Laboratory
}

\author{
U.S. Department of Energy \\ USDOE Office of Science (SC), \\ Basic Energy Sciences (BES) (SC-22)
}

\footnotetext{
Notice: This manuscript has been co-authored by employees of Brookhaven Science Associates, LLC under Contract No. DE-SC0012704 with the U.S. Department of Energy. The publisher by accepting the manuscript for publication acknowledges that the United States Government retains a non-exclusive, paid-up, irrevocable, world-wide license to publish or reproduce the published form of this manuscript, or allow others to do so, for United States Government purposes.
} 


\section{DISCLAIMER}

This report was prepared as an account of work sponsored by an agency of the United States Government. Neither the United States Government nor any agency thereof, nor any of their employees, nor any of their contractors, subcontractors, or their employees, makes any warranty, express or implied, or assumes any legal liability or responsibility for the accuracy, completeness, or any third party's use or the results of such use of any information, apparatus, product, or process disclosed, or represents that its use would not infringe privately owned rights. Reference herein to any specific commercial product, process, or service by trade name, trademark, manufacturer, or otherwise, does not necessarily constitute or imply its endorsement, recommendation, or favoring by the United States Government or any agency thereof or its contractors or subcontractors. The views and opinions of authors expressed herein do not necessarily state or reflect those of the United States Government or any agency thereof. 


\title{
Impact of Multifunctional Bimetallic Materials on Lithium Battery Electrochemistry
}

\author{
Jessica L. Durham ${ }^{a}$, Altug S. Poyraz ${ }^{b}$, Esther S. Takeuchi ${ }^{a, b, c *}$, Amy C. Marschilok ${ }^{a, c}$, \\ Kenneth J. Takeuchi ${ }^{a, c *}$ \\ ${ }^{a}$ Department of Chemistry, Stony Brook University, Stony Brook, NY 11794, USA \\ ${ }^{b}$ Energy Sciences Directorate, Brookhaven National Laboratory, Upton, NY 11973, \\ USA \\ ${ }^{C}$ Department of Materials Science and Engineering, Stony Brook University, Stony \\ Brook, NY 11794, USA \\ *corresponding authors: (EST) esther.takeuchi@stonybrook.edu, (ACM) \\ amy.marschilok@stonybrook.edu, (KJT) kenneth.takeuchi.1@stonybrook.edu
}

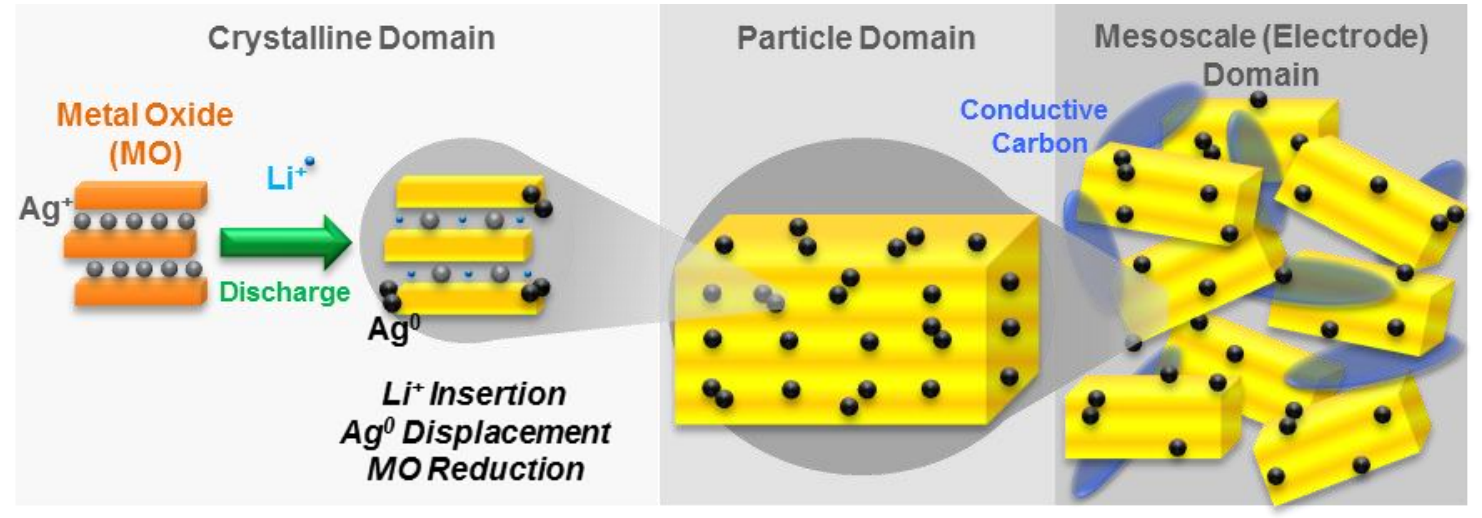

\section{Conspectus}

Electric energy storage devices such as batteries are complex systems comprised of a variety of materials with each playing separate yet interactive roles, complicated by length scale interactions occurring from the molecular to the mesoscale. Thus, addressing specific battery issues such as functional capacity requires a comprehensive perspective initiating with atomic level concepts. For example, the electroactive materials which contribute to the functional capacity in a battery comprise approximately $30 \%$ or less of the total device mass. Thus, the design and implementation of multifunctional materials can conceptually reduce or eliminate the contribution of passive materials to the size and mass of the final system. Material multi-functionality can be achieved through appropriate material design on the atomic level resulting in bimetallic electroactive materials where one metal cation forms mesoscale conductive networks upon discharge while the other metal cation can contribute to atomic level structure and net functional secondary capacity, a device level issue. Specifically, this Account provides insight into the multi-mechanism electrochemical redox processes of bimetallic cathode materials based on transition metal oxides (MM'O) or phosphorous oxides (MM'PO) where $\mathrm{M}=\mathrm{Ag}$ and $\mathrm{M}^{\prime}=\mathrm{V}$ or Fe. One discharge process can be described as reduction-displacement where $\mathrm{Ag}^{+}$is reduced to $\mathrm{Ag}^{0}$ and displaced from the parent structure. This reduction-displacement reaction in silver-containing bimetallic electrodes allows for the in-situ formation of a conductive network, enhancing the 
electrochemical performance of the electrode and reducing or eliminating the need for conductive additives. A second discharge process occurs through the reduction of the second transition metal, $\mathrm{V}$ or $\mathrm{Fe}$, where the oxidation state of the metal center is reduced and lithium cations are inserted into the structure. As both metal centers contribute to the functional capacity, determining the kinetically and thermodynamically preferred reduction processes at various states of discharge is critical to elucidating the mechanism. Specific advanced in-situ and ex-situ characterization techniques are conducive to gaining insight regarding the electrochemical behavior of these multifunctional materials over multiple length scales. At the material level, optical microscopy, scanning electron microscopy, and local conductivity measurement via a nanoprobe can track the discharge mechanism of an isolated single particle. At the mesoscale electrode level, in-situ data from synchrotron based energy dispersive X-ray diffraction (EDXRD) within fully intact steel batteries can be used to spatially map the distribution of silver metal generated through reduction displacement as a function of discharge depth and discharge rate. As illustrated here, appropriate design of materials with multiple electrochemically active metal centers and properties tuned through strategically conceptualized materials synthesis may provide a path toward the next generation of high energy content electroactive materials and systems. Full understanding of the multiple electrochemical mechanisms can be achieved only by utilizing advanced characterization tools over multiple length scales.

\subsection{Introduction}

In a conventional electrode design, the electroactive material is combined with a conductive additive where each material plays a distinct role. Through appropriate material design, multi-functionality can be achieved for electroactive bimetallic materials where each metal center contributes to electrode function in a distinctive manner. Specifically, bimetallic oxide (MM'O) or phosphate (MM'PO) materials can undergo reactions during discharge (lithiation), where one metal ion $\left(\mathrm{M}^{\mathrm{m}+}\right)$ is reduced to the metallic state $\left(\mathrm{M}^{0}\right)$ and repositioned externally to the original crystal through a reductiondisplacement process, while the other metal ion $\left(\mathrm{M}^{\mathrm{n}+}\right)$ is partially reduced and structurally contributes to the crystal framework. ${ }^{1-10}$

When $\mathrm{M}^{\mathrm{m}+}\left(\mathrm{Ag}^{+}\right.$or $\left.\mathrm{Cu}^{2+}\right)$ is part of the structure, $\mathrm{Ag}^{0}$ or $\mathrm{Cu}^{0}$ may form, which may positively impact the battery's relevant electrochemistry due to the high electrical conductivities of $\mathrm{Ag}^{0}$ and $\mathrm{Cu}^{0} .^{11,12}$ Copper and silver, while both coinage metals, behave quite differently in these bimetallic systems. While $\mathrm{Cu}^{2+}$ can be reduced to $\mathrm{Cu}^{0}$, it is often reintegrated into the layered structure upon charge $\mathrm{e}^{13-15}$ and may be so finely divided that there is no notable increase in conductivity. In contrast, the reductiondisplacement in silver vanadium phosphorous oxides, such as $\mathrm{Ag}_{2} \mathrm{VO}_{2} \mathrm{PO}_{4}$, has been demonstrated to generate an in-situ conductive percolation $\mathrm{Ag}^{0}$ network with an accompanying increase in conductivity of 15,000 -fold. ${ }^{16}$ The second metal center, $\mathrm{M}^{\mathrm{n}+}$ ( $\mathrm{V}, \mathrm{Fe}$, or W), may demonstrate multiple discharge/charge cycles in which both the oxidized and the reduced metal centers contribute structurally to the respective electrode materials. ${ }^{13,17-19}$ Notably, silver does not re-enter the parent structure upon charge ${ }^{19}$ thus the conductivity benefit of the $\mathrm{Ag}^{0}$ framework can be sustained upon full discharge and subsequent charge. Conceptually, on a volumetric energy density basis, 
the replacement of carbon by silver could provide a five fold reduction in the volume of the conductive component. Consequently, bimetallic materials can be designed to contribute in two distinct ways to battery electrochemistry and display unique, reproducible, and desirable properties which are tunable through synthetic manipulation.

This Account provides a focused discussion of the multi-functional electrochemistry of bimetallic cathode materials (transition metal oxides (MM'O) or phosphorous oxides (MM'PO) where $\mathrm{M}=\mathrm{Ag}$ and $\mathrm{M}^{\prime}=\mathrm{V}, \mathrm{Fe}$ ). Mechanistically, a reduction-displacement takes place where $\mathrm{Ag}^{+}$is reduced to $\mathrm{Ag}^{0}$ and displaced from the parent structure. A second type of discharge process occurs through the reduction of the second transition metal, $\mathrm{V}$ or Fe, accompanied by lithium cation insertion into the structure. Characterization of the multi-mechanism discharge process is highlighted where the use of advanced characterization techniques over multiple length scales yields insight regarding the electrochemical behavior of these multifunctional materials.

\subsection{Bimetallic Silver Vanadium Oxide $\left(\mathrm{Ag}_{2} \mathrm{~V}_{4} \mathrm{O}_{11}\right)$ and Silver Vanadium Phosphorous Oxides $\left(\mathrm{Ag}_{2} \mathrm{VO}_{2} \mathrm{PO}_{4}, \mathrm{Ag}_{0.48} \mathrm{VOPO}_{4}, \mathrm{Ag}_{2} \mathrm{VP}_{2} \mathrm{O}_{8}\right)$}

The lithium/silver vanadium oxide $\left(\mathrm{Li} / \mathrm{Ag}_{2} \mathrm{~V}_{4} \mathrm{O}_{11}\right)$ system has been successfully commercialized and is commonly used as the power source for implantable cardiac defibrillators (ICDs). ${ }^{20,21}$ For lithium primary batteries, non-lithiated materials such as $\mathrm{Ag}_{2} \mathrm{~V}_{4} \mathrm{O}_{11}$ can be implemented as cathodes. The selection of silver vanadium oxide for the application was motivated by its ability to create a conductive network within the cathode due to reduction of $\mathrm{Ag}^{+}$, therefore, providing the high pulse power demanded by the ICD. $22,23,24$ Analysis of $\mathrm{Li}_{x} \mathrm{Ag}_{2} \mathrm{~V}_{4} \mathrm{O}_{11}$ discharge products $\left(x=\right.$ moles of $\mathrm{Li}^{+}$ inserted) indicated that the reduction of $\mathrm{Ag}^{+}$to $\mathrm{Ag}^{0}$ occurs from $0<x<2.4$ with partial reduction of vanadium $(\mathrm{V})$ occurring simultaneously. ${ }^{25,26,27}$ The reduction of the silver cation contributes $\sim 30 \%$ of the capacity and significantly improves the cathode conductivity. ${ }^{25}$ In the region $2.4<x<3.8$, the discharge process is dominated by reduction of $\mathrm{V}^{5+}$ to $\mathrm{V}^{4+}$. Upon continued reduction to $x>3.8$, reduction of $\mathrm{V}^{4+}$ to $\mathrm{V}^{3+}$ is observed.

The investigation of silver vanadium phosphorous oxide materials such as $\mathrm{Ag}_{2} \mathrm{VO}_{2} \mathrm{PO}_{4}, \mathrm{Ag}_{0.48} \mathrm{VOPO}_{4}$, and $\mathrm{Ag}_{2} \mathrm{VP}_{2} \mathrm{O}_{8}$ was motivated by increased structural stability provided by the inclusion of the phosphate structure. The stability was demonstrated by decreased solubility, providing the opportunity for increased battery lifetime..$^{28-31}$

Structure. $\mathrm{Ag}_{2} \mathrm{~V}_{4} \mathrm{O}_{11}, \mathrm{Ag}_{2} \mathrm{VO}_{2} \mathrm{PO}_{4}, \mathrm{Ag}_{0.48} \mathrm{VOPO}_{4}$, and $\mathrm{Ag}_{2} \mathrm{VP}_{2} \mathrm{O}_{8}$ are layered bimetallic materials containing silver $\left(\mathrm{Ag}^{+}\right)$and vanadium $\left(\mathrm{V}^{4+5+}\right)$ in which silver cations reside between vanadium oxide or phosphate layers. ${ }^{10}$ The structures are illustrated in Figure $1^{11,32-34}$ where the core structural unit consists of distorted $\mathrm{VO}_{6}$ octahedra which link through edges or corners to other $\mathrm{VO}_{6}$ octahedra or $\mathrm{PO}_{4}$ tetrahedra to form infinite chains or layers. The silver ions are stabilized in an octahedral coordination environment, typically surrounded by oxygen from $\mathrm{VO}_{6}$ while water molecules also cooccupy the interlayers in $\mathrm{Ag}_{0.48} \mathrm{VOPO}_{4}$. The layered motif of these materials permits 
mobility of silver cations within the interlayer space, contributing to the high capacity which can reach up to $450 \mathrm{mAh} / \mathrm{g}$ (Table 1) and high pulse capability. ${ }^{10,19,35-41}$

Electrochemical Reduction. Despite the structural similarities of silver vanadium oxide and silver vanadium phosphate materials, the electrochemical behavior of each material varies. Discharge profiles of the materials are shown in Figure 2 and demonstrate single or multiple plateaus. ${ }^{37,39,42,43} \mathrm{Ag}_{2} \mathrm{~V}_{4} \mathrm{O}_{11}$ displays two distinct plateaus at $2.7 \mathrm{~V}$ and $2.5 \mathrm{~V}$, while $\mathrm{Ag}_{2} \mathrm{VO}_{2} \mathrm{PO}_{4}$ demonstrates one long plateau at $2.7 \mathrm{~V}$. The vanadium oxidation state in $\mathrm{Ag}_{0.48} \mathrm{VOPO}_{4}$ is mixed valent $\left(\mathrm{V}^{+5} / \mathrm{V}^{4+}\right)$, while the vanadium center in $\mathrm{Ag}_{2} \mathrm{VP}_{2} \mathrm{O}_{8}$ is $\mathrm{V}^{4+}$. Synthetic approaches ${ }^{44,45}$ and the discharge mechanisms of the materials have been studied in detail using spectroscopic, ${ }^{18,46}$ magnetic susceptibility, ${ }^{47}$ conductivity, ${ }^{16,47}$ and diffraction techniques. ${ }^{37,48-50}$ As there are two metal centers, the reduction mechanisms relate to the oxidation state of vanadium and silver content of the material and the overall discharge mechanisms are summarized in Table 1. Notably, the discharge rate can have profound effects on the reaction progression and impact the relative ratio of $\mathrm{Ag}^{+}$and $\mathrm{V}^{5+} / \mathrm{V}^{4+} / \mathrm{V}^{3+}$ reduction. ${ }^{35,50}$

Particle Level Characterization. Upon reduction of the bimetallic vanadium-based materials, nano-sized clusters of metallic silver form on the surfaces of particles which can be detected by scanning electron microscopy (SEM) (Figure 3) ${ }^{16} \mathrm{~A}$ limited number of quantitative electrochemical studies of individual particles have been reported where the lithiation of individual particles of pure active material was conducted. These studies provide the ability to interrogate the intrinsic properties of the active material directly without complications of other components commonly present in electrodes such as binders and conductive additives. Optical visualization of the reduction-displacement process upon discharge of a single particle of $\mathrm{Ag}_{2} \mathrm{VO}_{2} \mathrm{PO}_{4}$ was recently reported (Figure 4a). ${ }^{51}$ During discharge, a transparent orange $\mathrm{Ag}_{2} \mathrm{VO}_{2} \mathrm{PO}_{4}$ crystal gradually turned black as the electrochemical reaction front moved along the $c$-direction of the crystal. The concomitant color change is related to the formation of silver nanoparticles on the surface of the crystal as well as the formation of a vanadium bronze-type material. Conductivity measurements of a partially discharged $\mathrm{Ag}_{2} \mathrm{VO}_{2} \mathrm{PO}_{4}$ particle were executed by using a scanning transmission microscopy tip on orange (undischarged) and dark (discharged) regions (Figure 4b). The data revealed that the black (discharged) region of $\mathrm{Ag}_{2} \mathrm{VO}_{2} \mathrm{PO}_{4}$ possesses 100,000 times lower resistance compared to the undischarged, orange region, consistent with bulk $\mathrm{Ag}_{2} \mathrm{VO}_{2} \mathrm{PO}_{4}$ electrode data. ${ }^{16}$

Mesoscale Electrode Characterization: Pure Electroactive Material. X-ray diffraction (XRD) can be used to detect low quantities of crystalline $\mathrm{Ag}^{0}$, formed upon reduction displacement, since $\mathrm{Ag}^{0}$ is a high $\mathrm{Z}$ element which displays intense diffraction peaks. ${ }^{37}$ Electrodes comprised of pure $\mathrm{Ag}_{2} \mathrm{VO}_{2} \mathrm{PO}_{4}$ were electrochemically reduced under a constant current $\mathrm{C} / 200$ rate, and the process was monitored via ex-situ XRD. ${ }^{16}$ As discharge progressed, the parent $\mathrm{Ag}_{2} \mathrm{VO}_{2} \mathrm{PO}_{4}$ peak intensity decreased monotonically while the $\mathrm{Ag}^{0}$ peak intensity increased up to $x=2.4$ molar electron equivalents of reduction in $\mathrm{Li}_{x} \mathrm{Ag}_{2-x} \mathrm{VO}_{2} \mathrm{PO}_{4}$. If the mechanism were to proceed stepwise with complete reduction of $\mathrm{Ag}^{+} \rightarrow \mathrm{Ag}^{0}$, followed by reduction of $\mathrm{V}^{5+}$, then the $\mathrm{Ag}^{0}$ peak intensity would be expected to reach its maximum at $x=2.0$. Therefore, these XRD data 
suggested reduction of $\mathrm{Ag}^{+}$and $\mathrm{V}^{5+}$ can occur in parallel, as confirmed by magnetic susceptibility of vanadium ${ }^{47}$ and $X$-ray absorption spectroscopy ${ }^{18}$ studies. AC impedance indicated an increase in conductivity of $>15,000$ times as the cell was discharged from zero to 0.08 molar electron equivalents or $2 \%$ of the cell theoretical capacity, demonstrating the fundamental phenomenon that structural incorporation of a metal ion, reduced to metallic particles on initiation of reduction, can lead to a significant conductivity increase in an electrode of pure material which is free of conductive additives.

Electrochemical cells with X-ray transparent windows are important in-situ characterization tools, especially for lithium batteries; however, they do not fully replicate conditions within fully functioning cells. Energy dispersive X-ray diffraction (EDXRD) can penetrate engineered bulk materials permitting measurements through the stainless steel can of intact, operational coin cells and has achieved adequate spatial resolution to detect the in-situ formation of $\mathrm{Ag}^{0}$ during reduction displacement of silver in $\mathrm{Ag}_{2} \mathrm{VO}_{2} \mathrm{PO}_{4}$ and $\mathrm{Ag}_{2} \mathrm{VP}_{2} \mathrm{O}_{8}$ cathodes. ${ }^{37,48-50}$ In particular, EDXRD provides spatially resolved information critical to mechanistic interpretation of the $\mathrm{Ag}^{+}$reductiondisplacement reaction within the physical confines of battery electrodes and gives insight into electronic versus ionic limitations of the discharge process as well as rate dependent behavior. ${ }^{50}$

In 2013, the first in-situ EDXRD analysis of an intact coin-sized lithium anode cell was performed for a pelletized $\mathrm{Ag}_{2} \mathrm{VO}_{2} \mathrm{PO}_{4}$ cathode. ${ }^{37} \mathrm{~A}$ representative experimental configuration of EDXRD studies is shown in Figure 5a. In a partially discharged cell, $\mathrm{Ag}^{0}$ was observed on the side of the cathode nearest to the $\mathrm{Li}$-anode while $\mathrm{Ag}_{2} \mathrm{VO}_{2} \mathrm{PO}_{4}$ was dominant on the side of the cathode facing the stainless steel cell, illustrating a clear reaction front within the cathode. A fully discharged cell showed the presence of $\mathrm{Ag}^{0}$ throughout the cathode. ${ }^{37}$ The in-situ EDXRD data agrees with previous ex-situ $X R D$ data which established that the multi-mechanism processes during discharge of $\mathrm{Ag}_{2} \mathrm{VO}_{2} \mathrm{PO}_{4}$ (i.e. $\mathrm{Ag}^{+} \rightarrow \mathrm{Ag}^{0}$ and vanadium reduction) occur in parallel.

In addition to locational dependence as a function of discharge depth, lithiation and reduction-displacement mechanisms can be rate-dependent in pure $\mathrm{Ag}_{2} \mathrm{VP}_{2} \mathrm{O}_{8}$ cathodes. EDXRD analysis of lithium cells containing $\mathrm{Ag}_{2} \mathrm{VP}_{2} \mathrm{O}_{8}$ cathodes was conducted on cells discharged at slower $(\mathrm{C} / 1440)$ and faster $(\mathrm{C} / 168)$ rates (Figure $5 \mathrm{~b} / 5 \mathbf{c}){ }^{50}$ Evidence of $\mathrm{Ag}^{0}$ was observed on the surface of the lithium anode and attributed to ion-exchange $\left(\mathrm{Li}^{+}\right.$for $\left.\mathrm{Ag}^{+}\right)$of the cathode material $\left(\mathrm{Ag}^{+}\right)$with the electrolyte $\left(\mathrm{Li}^{+}\right)$while $\mathrm{Ag}^{0}$ observed near the stainless steel can was associated with reduction displacement. ${ }^{28,51}$ In $\mathrm{Ag}_{2} \mathrm{VP}_{2} \mathrm{O}_{8}$ cathodes, the quantity, distribution, and crystallite size of $\mathrm{Ag}^{0}$ show a strong dependence on discharge rate. $\mathrm{Ag}_{2} \mathrm{VP}_{2} \mathrm{O}_{8}$ cathodes subjected to high discharge rates produced highly crystalline $\mathrm{Ag}^{0}(\sim 500 \mathrm{~nm}$ crystallite size) and localized formation of $\mathrm{Ag}^{0}$ particles (indicative of uneven discharge), whereas slower discharge rates afforded more evenly distributed, nanocrystalline $\mathrm{Ag}^{0}$ ( $\sim 5 \mathrm{~nm}$ crystallite size), suggesting homogeneous lithiation (Figure $5 \mathbf{b} / \mathbf{5 c}$ ).$^{50}$ Cells discharged at faster rates demonstrated approximately $3 \mathrm{X}$ higher charge transfer resistance compared to cells discharged at slower rates. Slower discharge rates produced almost $2 \mathrm{X}$ as much silver as the $\mathrm{Li} / \mathrm{Ag}_{2} \mathrm{VP}_{2} \mathrm{O}_{8}$ cells discharged at faster rates, up to 1 electron equivalent, 
suggesting that reduction of silver is more prominent than reduction of $\mathrm{V}^{4+}$ species at slow discharge rates. Notably, the uniform dispersion of nanocrystalline $\mathrm{Ag}^{0}$, observed under the slower discharge rate, reduces the resulting impedance.

\section{Mesoscale Electrode Characterization: The Role of Conductive Additives.}

Electronic conductivity is essential for full utilization of cathode materials and increases the electrode's ability to achieve high delivered capacities, ideally approaching theoretical values. Consequently, conductive additives, including conductive polymers and carbonaceous additives, are widely utilized during cathode preparation. Traditional conductive additives are electrochemically inactive and decrease the gravimetric and/or volumetric capacity of the composite cathode. In comparison, the formation of $\mathrm{Ag}^{0}$ metal nanoparticles in $\mathrm{Ag}_{2} \mathrm{~V}_{4} \mathrm{O}_{11}$ and $\mathrm{Ag}_{2} \mathrm{VO}_{2} \mathrm{PO}_{4}$ substantially contributes to capacity. The volume percentage of $\mathrm{Ag}^{0}$ required to achieve a percolation threshold has been estimated to be $\sim 0.3 \%$ of the total volume of $\mathrm{Ag}_{2} \mathrm{VP}_{2} \mathrm{O}_{8} .{ }^{48} \mathrm{Thus}$, at $<1 \%$ electrochemical reduction for $\mathrm{Ag}_{2} \mathrm{VP}_{2} \mathrm{O}_{8}$, sufficient silver can be generated to reach the percolation threshold and form a conductive cathode matrix. These results indicate that the silver content in bimetallic $\mathrm{Ag}_{2} \mathrm{~V}_{4} \mathrm{O}_{11}$ and $\mathrm{Ag}_{2} \mathrm{VO}_{2} \mathrm{PO}_{4}$ materials is more than sufficient to achieve a conductive network.

The effect of conductive additives, in relation to $\mathrm{Ag}^{0}$ displacement, in $\mathrm{Ag}_{2} \mathrm{VP}_{2} \mathrm{O}_{8}$ cathodes was recently investigated. ${ }^{49} \mathrm{~A}$ combination of in-situ and ex-situ characterization techniques (EDXRD, X-ray absorption (XAS), and AC impedance) was utilized to determine the role of a conductive carbon additive at various depths of discharge in $\mathrm{Li} / \mathrm{Ag}_{2} \mathrm{VP}_{2} \mathrm{O}_{8}$ cells. The carbon additive enabled the formation of $\mathrm{Ag}^{0}$ with uniform distribution upon reduction largely independent of discharge rate. EDXRD spectra of discharged cathodes showed larger full width at half-maximum (FWHM) values and lower intensities of $\mathrm{Ag}^{0}$ peaks in cathodes discharged at faster $(\mathrm{C} / 168)$ rates, consistent with a smaller crystallite size $(11 \mathrm{~nm})$, while an $\mathrm{Ag}^{0}$ crystallite size of 40 $\mathrm{nm}$ was observed in cells discharged at slower $(\mathrm{C} / 1440)$ rates. For cells containing carbon in the cathode, the impedance responses were dependent on the size of $\mathrm{Ag}^{0}$ nanoparticles, rather than the quantity of silver, and lower resistivity was observed for cells discharged at fast rates with smaller $\mathrm{Ag}^{0}$ nanoparticles which indicates establishment of a superior conductive network. The transition of $\mathrm{Ag}^{+} \rightarrow \mathrm{Ag}^{0}$ was also monitored by ex-situ XAS and linear combination fitting determined that silver metal content was equivalent for both fast and slow rates and increases with depth of discharge. The data affirm that the inclusion of conductive carbon in the cathode enables more uniform discharge and distribution of $\mathrm{Ag}^{0}$ metal. Notably, even in the presence of a carbon additive in the cathode, the impedance of the cells decreases significantly on initiation of discharge indicating the additional benefit from the formation of silver metal. Thus, a pre-existing percolation network may be a necessary, but not a sufficient condition, for full utilization of the electroactive material. ${ }^{52}$

\subsection{Bimetallic Silver Iron Oxide $\left(\mathrm{AgFeO}_{2}\right)$}

Structure. Silver ferrite $\left(\mathrm{AgFeO}_{2}\right)$ is a bimetallic oxide containing alternating layers of edge-shared $\mathrm{FeO}_{6}$ octahedra ( $\mathrm{Fe}^{3+}$ oxidation state) with layers of close-packed $\mathrm{Ag}^{+}$ cations between. The $\mathrm{Ag}^{+}$transition metal cations are linearly coordinated between two oxygen molecules in the parallel iron oxide layers. Two major polytypes of this 
delafossite compound exist upon crystallization, either a rhombohedral (3R) or hexagonal $(2 \mathrm{H})$ geometry is possible based on the manner in which alternating iron oxide layers stack (Figure 6a/6b). ${ }^{53,54}$ The layers of the $3 \mathrm{R}$ polytype stack in an $\mathrm{AaBbCcAaBbCc}$ sequence while the $2 \mathrm{H}$ polytype layers stack as $\mathrm{AaBbAaBb}$. Synthesis of silver ferrite via a co-precipitation reaction has been accomplished. ${ }^{55}$ Further, silver ferrite/maghemite composites with $\mathrm{Ag} / \mathrm{Fe}$ ratios ranging from 0.2-1.0 have also been prepared via direct in-situ formation through co-precipitation. ${ }^{56}$ The nanocrystalline silver ferrite $(10-18 \mathrm{~nm})$ as a mixture of $2 \mathrm{H}$ and $3 \mathrm{R}-\mathrm{AgFeO}_{2}$ phases was identified via $\mathrm{XRD}$ and the poorly crystalline iron oxide phase (maghemite, $\mathrm{y}-\mathrm{Fe}_{2} \mathrm{O}_{3}$ ) was indicated by Raman spectroscopy (Figure 6c).

Electrochemical Reduction. Silver ferrite has recently been studied as a cathode material for lithium based batteries and displays multi-mechanism behavior. ${ }^{55,56}$ Examination of the discharge capacity revealed a decrease in delivered capacity between cycles 1 and 2 where the capacity difference was directly proportional to the $\mathrm{Ag}^{+}$content (Figure $6 \mathrm{~d}$ ) ${ }^{56}$ which can be rationalized as the reduction displacement of $\mathrm{Ag}^{+}$to $\mathrm{Ag}^{0}$. XRD of the cathode after discharge to 1 electron demonstrates decreased peak intensities of $\mathrm{AgFeO}_{2}$ (i.e. amorphization of crystal structure) but no observable $\mathrm{Ag}^{0}$ peaks. The absence of $\mathrm{Ag}^{0}$ in the XRD suggests that the displaced $\mathrm{Ag}^{0}$ is nanocrystalline and cannot be detected by diffraction. AC impedance measurements demonstrate nearly a 6,000-fold decrease in resistivity of the silver ferrite/maghemite system upon discharge to 2 electron equivalents which can be correlated to the formation of $\mathrm{Ag}^{0} .{ }^{55}$ Calculations show that a discharge of 0.05 electron equivalents (2.5\% discharge) or greater would afford sufficient $\mathrm{Ag}^{0}$ content in $\mathrm{AgFeO}_{2}$ and silver ferrite/maghemite materials necessary to achieve a conductive network. The silver ferrite/maghemite composite material with the lowest silver content, $0.2 \mathrm{Ag} / \mathrm{Fe}$, displayed a capacity of $130 \mathrm{mAh} / \mathrm{g}$ with negligible fade over 50 cycles, suggesting that the redox process the Fe center is largely electrochemically reversible, while that at the $\mathrm{Ag}$ center is not. ${ }^{56}$ Such results demonstrate the advantage of incorporating bimetallic materials in the direct preparation of nanocomposites for use as cathodes in secondary batteries. Notably, direct preparation of the nanocomposite gave improved electrochemical performance relative to mechanically mixing two separate oxide materials, likely due to the physiochemical differences between a mechanical mixture and a directly prepared bimetallic multifunctional material.

\subsection{Conclusion}

The presence of two distinct electrochemically active metal cations in bimetallic cathode materials in lithium batteries can provide complementary battery electrochemistry, such as high current capabilities with minimal conductive additives. Further, by combining two diverse metals within one material, the effects are tunable via synthesis, given careful control of the ratios of the metals within the phase. This Account describes several layered structures with crystalline motifs that provide enhanced mobility of $\mathrm{Li}^{+}$and $\mathrm{Ag}^{+}$ions. The multi-mechanism discharge process of silver-containing bimetallic cathodes enables the reduction displacement of $\mathrm{Ag}^{0}$, which can initiate the in-situ formation of a conductive percolation network of metallic nanoparticles, and insertion/de-insertion of lithium ions within a metal oxide structure. 
Single-particle electrochemistry has provided considerable insight into the steps associated with the electrochemical behavior of multifunctional bimetallic materials. Spatial characterization of the discharge processes within a cathode has been demonstrated using synchrotron based energy dispersive X-ray diffraction (EDXRD) of fully intact steel battery cells. Multifunctional electrode materials can provide a path toward increased energy density. Investigation over multiple length scales is necessary to effectively characterize the electrochemical processes.

\section{Acknowledgement}

The authors acknowledge the Center for Mesoscale Transport Properties, an Energy Frontier Research Center supported by the U.S. Department of Energy, Office of Science, Basic Energy Sciences, under award \#DE-SC0012673 for financial support. The authors commend the Department of Energy for the vision to create Energy Frontier Research Centers which enable multi-disciplinary research over multiple length scales. This research used resources of the Center for Functional Nanomaterials, which is a US DOE Office of Science Facility, at Brookhaven National Laboratory under Contract No. DE-SC0012704. Use of the National Synchrotron Light Source beamline X17B1 was supported by DOE contract DE-AC02-98CH10886.

\section{Biographical Information}

Jessica L. Durham obtained a BS and MS in chemistry from Illinois State University. She is currently a senior PhD candidate in the Department of Chemistry at Stony Brook University conducting research under the supervision of Dr. Esther S. Takeuchi, Dr. Kenneth J. Takeuchi, and Dr. Amy C. Marschilok. Her research includes the electrochemical investigation of nanocrystalline bimetallic iron and manganese oxides (prepared via aqueous, low-temperature approaches which are eco-friendly and economically feasible) as viable cathode materials for lithium batteries.

Altug S. Poyraz is a post doctoral research associate at Brookhaven National Laboratory under the supervision of Prof. Esther S. Takeuchi. Dr. Poyraz received his BS and MS from Bilkent University Chemistry department and a PhD in chemistry from the University of Connecticut. His research focuses on the synthesis and characterization of transition metal oxide based cathode materials for rechargeable lithium batteries.

Esther S. Takeuchi is a SUNY Distinguished Professor in the Departments of Chemistry and Materials Science and Engineering at Stony Brook University and holds a joint appointment at Brookhaven National Laboratory. She received a BA in chemistry and history from the University of Pennsylvania and a PhD in chemistry from Ohio State University. Prior to her academic career, she conducted battery research in industry, particularly for implantable applications. She is a member of National Academy of Engineering, National Inventors Hall of Fame, and National Academy of Innovation and has received the National Medal of Technology and Innovation. Her research focus is on understanding governing mechanisms related to energy storage. 
Amy C. Marschilok is a Research Professor in the Departments of Materials Science and Engineering and Chemistry at Stony Brook University. She received her BA and $\mathrm{PhD}$ in Chemistry from the University at Buffalo. She was previously employed at Greatbatch Inc., where she was recognized as a Visionary of the Year. She received the Leadership Award, Professional Service Category, from the Western New York YWCA. She was also recognized as a Woman of Distinction by the Girl Scouts of Western New York. Her research involves synthesis, advanced characterization, and electrochemical study of novel materials and systems for energy storage.

Kenneth J. Takeuchi is a SUNY Distinguished Teaching Professor in the Department of Chemistry at Stony Brook University. He holds a BS in chemistry from the University of Cincinnati and a PhD in chemistry from The Ohio State University and is a Fellow of the American Chemical Society and a Fellow of the American Association for the Advancement of Science. Professor Takeuchi has received over 20 regional and national awards for excellence in teaching and mentoring. His research involves the synthesis and utility of inorganic materials towards energy storage with a recent focus on synthetic development for crystallite size control. 


\section{References}

(1) Goodenough, J. B.: Evolution of Strategies for Modern Rechargeable Batteries. Acc. Chem. Res. 2013, 46, 1053-1061.

(2) Chen, J.; Cheng, F.: Combination of Lightweight Elements and Nanostructured Materials for Batteries. Acc. Chem. Res. 2009, 42, 713-723.

(3) Cheng, F.; Chen, J.: Transition Metal Vanadium Oxides and Vanadate Materials for Lithium Batteries. J Mater. Chem. 2011, 21, 9841-9848.

(4) Palacin, M. R.: Recent Advances in Rechargeable Battery Materials: A Chemist's Perspective. Chem. Soc. Rev. 2009, 38, 2565-2575.

(5) Cabana, J.; Monconduit, L.; Larcher, D.; Palacin, M. R.: Beyond Intercalation-Based Li-lon Batteries: The State of the Art and Challenges of Electrode Materials Reacting Through Conversion Reactions. Adv. Mater. 2010, 22, E170-E192.

(6) Reddy, M. V.; Subba Rao, G. V.; Chowdari, B. V. R.: Metal Oxides and Oxysalts as Anode Materials for Li lon Batteries. Chem. Rev. 2013, 113, 5364-5457.

(7) Yuan, C. Z.; Wu, H. B.; Xie, Y.; Lou, X. W.: Mixed Transition-Metal Oxides: Design, Synthesis, and Energy-Related Applications. Angew. Chem. Int. Ed. 2014, 53, 1488-1504.

(8) Wu, F. F.; Bai, J.; Feng, J. K.; Xiong, S. L.: Porous Mixed Metal Oxides: Design, Formation Mechanism, and Application in Lithium-Ion Batteries. Nanoscale 2015, 7, 17211-17230.

(9) Zhao, Y.; Li, X.; Yan, B.; Xiong, D.; Li, D.; Lawes, S.; Sun, X.: Recent Developments and Understanding of Novel Mixed Transition-Metal Oxides as Anodes in Lithium lon Batteries. Adv. Energy Mater. 2016, 6, 1502175.

(10) Takeuchi, K. J.; Marschilok, A. C.; Davis, S. M.; Leising, R. A.; Takeuchi, E. S.: Silver Vanadium Oxides and Related Battery Applications. Coord. Chem. Rev. 2001, 219-221, 283-310.

(11) Onoda, M.; Kanbe, K.: Crystal Structure and Electronic Properties of the $\mathrm{Ag}_{2} \mathrm{~V}_{4} \mathrm{O}_{11}$ Insertion Electrode. J Phys. Condens. Matter 2001, 13, 6675-6685.

(12) Linden, D.; Reddy, T. B.: Handbook of Batteries $3^{\text {rd }}$ Edition; McGraw-Hill: New York, NY, 2002.

(13) Morcrette, M.; Rozier, P.; Dupont, L.; Mugnier, E.; Sannier, L.; Galy, J.; Tarascon, J. M.: A Reversible Copper Extrusion-Insertion Electrode for Rechargeable Li Batteries. Nature Mater. 2003, 2, 755-761.

(14) Li, Y. R.; Marschilok, A. C.; Takeuchi, E. S.; Takeuchi, K. J.: Synthesis of Copper Birnessite, $\mathrm{Cu}_{x} \mathrm{MnO}_{y} \cdot n \mathrm{H}_{2} \mathrm{O}$ with Crystallite Size Control: Impact of Crystallite Size on Electrochemistry. J. Electrochem. Soc. 2016, 163, A281-A285.

(15) Pelliccione, C. J.; Li, Y. R.; Marschilok, A. C.; Takeuchi, K. J.; Takeuchi, E. S.: X-Ray Absorption Spectroscopy of Lithium Insertion and De-Insertion in Copper Birnessite Nanoparticle Electrodes. Phys. Chem. Chem. Phys. 2016, 18, 2959-2967.

(16) Takeuchi, E. S.; Marschilok, A. C.; Tanzil, K.; Kozarsky, E. S.; Zhu, S.; Takeuchi, K. J.: Electrochemical Reduction of Silver Vanadium Phosphorous Oxide, $\mathrm{Ag}_{2} \mathrm{VO}_{2} \mathrm{PO}_{4}$ : The Formation of Electrically Conductive Metallic Silver Nanoparticles. Chem. Mater. 2009, 21, 4934-4939.

(17) Li, C.-L.; Fu, Z.-W.: Nano-Sized Copper Tungstate Thin Films as Positive Electrodes for Rechargeable Li Batteries. Electrochim. Acta 2008, 53, 4293-4301. 
(18) Patridge, C. J.; Jaye, C.; Abtew, T. A.; Ravel, B.; Fischer, D. A.; Marschilok, A. C.; Zhang, P.; Takeuchi, K. J.; Takeuchi, E. S.; Banerjee, S.: An X-Ray Absorption Spectroscopy Study of the Cathodic Discharge of $\mathrm{Ag}_{2} \mathrm{VO}_{2} \mathrm{PO}_{4}$ : Geometric and Electronic Structure Characterization of Intermediate phases and Mechanistic Insights. J Phys. Chem. C 2011, 115, 14437-14447.

(19) Marschilok, A. C.; Kim, Y. J.; Takeuchi, K. J.; Takeuchi, E. S.: Silver Vanadium Phosphorous Oxide, $\mathrm{Ag}_{0.48} \mathrm{VOPO}_{4}$ : Exploration as a Cathode Material in Primary and Secondary Battery Applications. J Electrochem. Soc. 2012, 159, A1690A1695.

(20) Bock, D. C.; Marschilok, A. C.; Takeuchi, K. J.; Takeuchi, E. S.: Batteries Used to Power Implantable Biomedical Devices. Electrochim. Acta 2012, 84, 155-164.

(21) Takeuchi, E. S.; Leising, R. A.: Lithium Batteries for Biomedical Applications. MRS Bull. 2002, 27, 624-627.

(22) Takeuchi, E. S.: Reliability Systems for Implantable Cardiac Defibrillator Batteries. J. Power Sources 1995, 54, 115-119.

(23) Takeuchi, K. J.; Marschilok, A. C.; Davis, S. M.; Leising, R. A.; Takeuchi, E. S.: Silver vanadium oxides and related battery applications. Coordination Chemistry Reviews 2001, 219-221, 283-310.

(24) Leising, R. A.; Takeuchi, E. S.: Solid-State Synthesis and Characterization of Silver Vanadium Oxide for Use as a Cathode Material for Lithium Batteries. Chem. Mater. 1994, 6, 489-495.

(25) Leising, R. A.; Thiebolt, W. C., III; Takeuchi, E. S.: Solid-State Characterization of Reduced Silver Vanadium Oxide from the Li/SVO Discharge Reaction. Inorg. Chem. 1994, 33, 5733-5740.

(26) Takeuchi, E. S.; Thiebolt, W. C., III: The Reduction of Silver Vanadium Oxide in Lithium/Silver Vanadium Oxide Cells. J. Electrochem. Soc. 1988, 135, 26912694.

(27) Leifer, N. D.; Colon, A.; Martocci, K.; Greenbaum, S. G.; Alamgir, F. M.; Reddy, T. B.; Gleason, N. R.; Leising, R. A.; Takeuchi, E. S.: Nuclear Magnetic Resonance and X-Ray Absorption Spectroscopic Studies of Lithium Insertion in Silver Vanadium Oxide Cathodes. J. Electrochem. Soc. 2007, 154, A500-A506.

(28) Bock, D. C.; Takeuchi, K. J.; Marschilok, A. C.; Takeuchi, E. S.: Silver Vanadium Oxide and Silver Vanadium Phosphorous Oxide Dissolution Kinetics: A Mechanistic Study with Possible Impact on Future ICD Battery Lifetimes. Dalton Trans. 2013, 42, 13981-13989.

(29) Bock, D. C.; Tappero, R. V.; Takeuchi, K. J.; Marschilok, A. C.; Takeuchi, E. S.: Mapping the Anode Surface-Electrolyte Interphase: Investigating a Life Limiting Process of Lithium Primary Batteries. ACS Appl. Mater. Interfaces 2015, 7, 5429-5437.

(30) Bock, D. C.; Marschilok, A. C.; Takeuchi, K. J.; Takeuchi, E. S.: A Kinetics and Equilibrium Study of Vanadium Dissolution from Vanadium Oxides and Phosphates in Battery Electrolytes: Possible Impacts on ICD Battery Performance. J. Power Sources 2013, 231, 219-225.

(31) Bock, D. C.; Takeuchi, K. J.; Marschilok, A. C.; Takeuchi, E. S.: Structural and Silver/Vanadium Ratio Effects on Silver Vanadium Phosphorous Oxide Solution Formation Kinetics: Impact on Battery Electrochemistry. Phys. Chem. Chem. Phys. 2015, 17, 2034-2042. 
(32) Kang, H. Y.; Wang, S. L.; Tsai, P. P.; Lii, K. H.: Hydrothermal Synthesis, Crystal-Structure, and lonic-Conductivity of $\mathrm{Ag}_{2} \mathrm{VO}_{2} \mathrm{PO}_{4}$ : A New Layered Phosphate of Vanadium(V). Dalton Trans. 1993, 1525-1528.

(33) Ayyappan, P.; Ramanan, A.; Torardi, C. C.: New Metal-Intercalated Layered Vanadyl Phosphates, $\mathrm{M}_{x} \mathrm{VOPO}_{4} \cdot \mathrm{yH}_{2} \mathrm{O}(\mathrm{M}=\mathrm{Ag}, \mathrm{Cu}, \mathrm{Zn})$. Inorg. Chem. 1998, 37, 3628-3634.

(34) Daidouh, A.; Veiga, M. L.; Pico, C.: Structure Characterization and Ionic Conductivity of $\mathrm{Ag}_{2} \mathrm{VP}_{2} \mathrm{O}_{8}$. J Solid State Chem. 1997, 130, 28-34.

(35) Crespi, A.; Schmidt, C.; Norton, J.; Chen, K. M.; Skarstad, P.: Modeling and Characterization of the Resistance of Lithium/SVO Batteries for Implantable Cardioverter Defibrillators. J Electrochem. Soc. 2001, 148, A30-A37.

(36) Marschilok, A. C.; Takeuchi, K. J.; Takeuchi, E. S.: Preparation and Electrochemistry of Silver Vanadium Phosphorous Oxide, $\mathrm{Ag}_{2} \mathrm{VO}_{2} \mathrm{PO}_{4}$. Electrochem. Solid-State Lett. 2009, 12, A5-A9.

(37) Takeuchi, E. S.; Lee, C. Y.; Chen, P. J.; Menard, M. C.; Marschilok, A. C.; Takeuchi, K. J.: Silver Vanadium Diphosphate $\mathrm{Ag}_{2} \mathrm{VP}_{2} \mathrm{O}_{8}$ : Electrochemistry and Characterization of Reduced Material Providing Mechanistic Insights. J Solid State Chem. 2013, 200, 232-240.

(38) Zhang, S. Y.; Li, W. Y.; Li, C. S.; Chen, J.: Synthesis, Characterization, and Electrochemical Properties of $\mathrm{Ag}_{2} \mathrm{~V}_{4} \mathrm{O}_{11}$ and $\mathrm{AgVO}_{3}$ 1-D Nano/Microstructures. J. Phys. Chem. B 2006, 110, 24855-24863.

(39) Sauvage, F.; Bodenez, V.; Vezin, H.; Morcrette, M.; Tarascon, J. M.; Poeppelmeier, K. R.: Structural and Transport Evolution in the $\mathrm{Li}_{x} \mathrm{Ag}_{2} \mathrm{~V}_{4} \mathrm{O}_{11}$ System. J. Power Sources 2010, 195, 1195-1201.

(40) Leising, R. A.; Takeuchi, E. S.: Solid-State Cathode Materials for Lithium Batteries: Effect of Synthesis Temperature on the Physical and Electrochemical Properties of Silver Vanadium Oxide. Chem. Mater. 1993, 5, 738-742.

(41) Leising, R. A.; Takeuchi, E. S.: Solid-State Synthesis and Characterization of Silver Vanadium Oxide for Use as a Cathode Material for Lithium Batteries. Chem. Mater. 1994, 6, 489-495.

(42) Kim, Y. J.; Lee, C. Y.; Marschilok, A. C.; Takeuchi, K. J.; Takeuchi, E. S.: $\mathrm{Ag}_{\mathrm{x}} \mathrm{VOPO}_{4}$ : A Demonstration of the Dependence of Battery-Related Electrochemical Properties of Silver Vanadium Phosphorous Oxides on Ag/V Ratios. J. Power Sources 2011, 196, 3325-3330.

(43) Takeuchi, E. S.; Marschilok, A. C.; Takeuchi, K. J.; Ignatov, A.; Zhong, Z.; Croft, M.: Energy Dispersive X-Ray Diffraction of Lithium-Silver Vanadium Phosphorous Oxide Cells: In Situ Cathode Depth Profiling of an Electrochemical ReductionDisplacement Reaction. Energy Environ. Sci. 2013, 6, 1465-1470.

(44) Huang, J.; Marschilok, A. C.; Takeuchi, E. S.; Takeuchi, K. J.: MicrowaveAssisted Synthesis of Silver Vanadium Phosphorus Oxide, $\mathrm{Ag}_{2} \mathrm{VO}_{2} \mathrm{PO}_{4}$ : Crystallite Size Control and Impact on Electrochemistry. Chem. Mater. 2016, 28, 2191-2199.

(45) Kim, Y. J.; Marschilok, A. C.; Takeuchi, K. J.; Takeuchi, E. S.: Silver vanadium phosphorous oxide, Ag2VO2PO4: Chimie douce preparation and resulting lithium cell electrochemistry. J. Power Sources 2011, 196, 6781-6787.

(46) Zhang, R.; Abtew, T. A.; Quackenbush, N. F.; Wangoh, L. W.; Huie, M.; Brady, A. B.; Bock, D.; Efstathiadis, H.; Whittingham, M. S.; Marschilok, A. C.; Takeuchi, 
K. J.; Takeuchi, E. S.; Zhang, P.; Piper, L. F. J.: Electrode Reaction Mechanism of $\mathrm{Ag}_{2} \mathrm{VO}_{2} \mathrm{PO}_{4}$ Cathode. Chem. Mater. 2016, 28, 3428-3434.

(47) Marschilok, A. C.; Kozarsky, E. S.; Tanzil, K.; Zhu, S.; Takeuchi, K. J.; Takeuchi, E. S.: Electrochemical Reduction of Silver Vanadium Phosphorous Oxide, $\mathrm{Ag}_{2} \mathrm{VO}_{2} \mathrm{PO}_{4}$ : Silver Metal Deposition and Associated Increase in Electrical Conductivity. J. Power Sources 2010, 195, 6839-6846.

(48) Kirshenbaum, K. C.; Bock, D. C.; Zhong, Z.; Marschilok, A. C.; Takeuchi, K. J.; Takeuchi, E. S.: In Situ Profiling of Lithium $/ \mathrm{Ag}_{2} \mathrm{VP}_{2} \mathrm{O}_{8}$ Primary Batteries Using Energy Dispersive X-Ray Diffraction. Phys. Chem. Chem. Phys. 2014, 16, 9138-9147.

(49) Kirshenbaum, K. C.; Bock, D. C.; Zhong, Z.; Marschilok, A. C.; Takeuchi, K. J.; Takeuchi, E. S.: Electrochemical Reduction of $\mathrm{Ag}_{2} \mathrm{VP}_{2} \mathrm{O}_{8}$ Composite Electrodes Visualized via In Situ Energy Dispersive X-Ray Diffraction (EDXRD): Unexpected Conductive Additive Effects. J Mater. Chem. A 2015, 3, 18027-18035.

(50) Kirshenbaum, K.; Bock, D. C.; Lee, C.-Y.; Zhong, Z.; Takeuchi, K. J.; Marschilok, A. C.; Takeuchi, E. S.: In Situ Visualization of $\mathrm{Li} / \mathrm{Ag}_{2} \mathrm{VP}_{2} \mathrm{O}_{8}$ Batteries: Revealing Rate-Dependent Discharge Mechanism. Science 2015, 347, 149-154.

(51) Kirshenbaum, K. C.; Bock, D. C.; Brady, A. B.; Marschilok, A. C.; Takeuchi, K. J.; Takeuchi, E. S.: Electrochemical Reduction of an $\mathrm{Ag}_{2} \mathrm{VO}_{2} \mathrm{PO}_{4}$ Particle: Dramatic Increase of Local Electronic Conductivity. Phys. Chem. Chem. Phys. 2015, 17, 11204-11210.

(52) Dudney, N. J.; Li, J.: Using All Energy in a Battery. Science 2015, 347, $131-132$.

(53) Okamoto, S.; Okamoto, S.; Ito, T.: Crystal Structure of a New Hexagonal Phase of Sllver Ferrite. Acta Crystallogr., Sect. B: Struct. Sci. 1972, 28.6, 1774-1777.

(54) Prewitt, C. T.; Shannon, R. D.; Rogers, D. B.: Chemistry of Noble Metal Oxides. II. Crystal Structures of $\mathrm{PtCoO}_{2}, \mathrm{PdCoO}_{2}, \mathrm{CuFeO}_{2}$, and $\mathrm{AgFeO}_{2}$. Inorg. Chem. 1971, 10, 719-723.

(55) Farley, K. E.; Marschilok, A. C.; Takeuchi, E. S.; Takeuchi, K. J.: Synthesis and Electrochemistry of Silver Ferrite. Electrochem. Solid-State Lett. 2012, 15, A23-A27.

(56) Durham, J. L.; Kirshenbaum, K.; Takeuchi, E. S.; Marschilok, A. C.; Takeuchi, K. J.: Synthetic Control of Composition and Crystallite Size of Silver Ferrite Composites: Profound Electrochemistry Impacts. Chem. Commun. 2015, 51, 51205123. 
a)

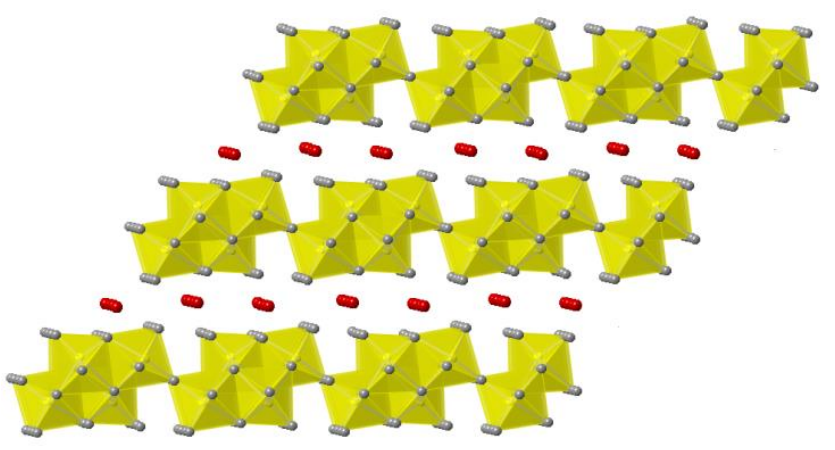

$\mathrm{Ag}_{2} \mathrm{~V}_{4} \mathrm{O}_{11}$

c)

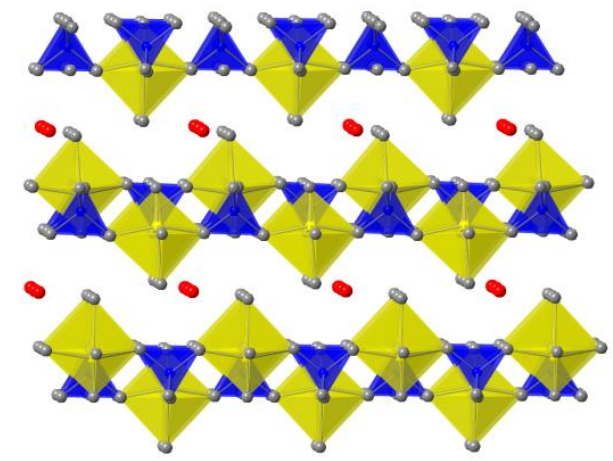

$\mathrm{Ag}_{0.48} \mathrm{VOPO}_{4}$ b)

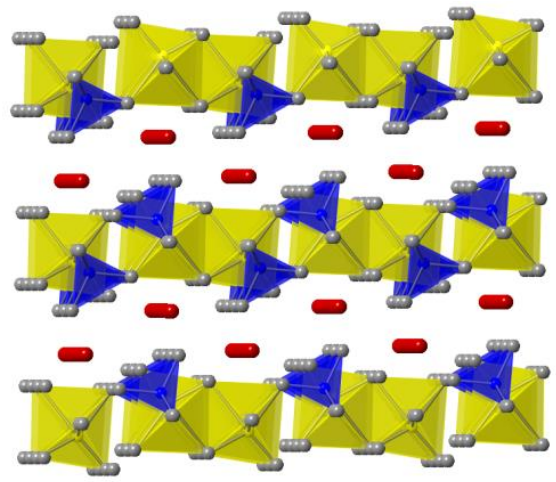

$\mathrm{Ag}_{2} \mathrm{VO}_{2} \mathrm{PO}_{4}$

d)
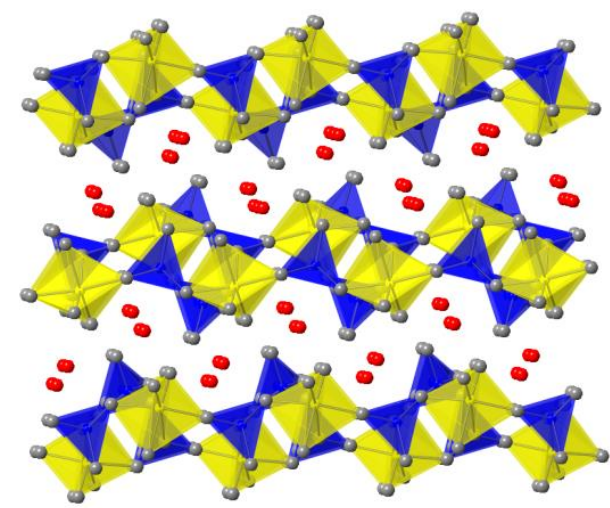

$\mathrm{Ag}_{2} \mathrm{VP}_{2} \mathrm{O}_{8}$

$\int_{0}^{\circ}=\left[\mathrm{VO}_{6}\right]$ octahedra $=\left[\mathrm{PO}_{4}\right]$ tetrahedra $\quad \cdot=$ Oxygen $\quad \cdot=$ Silver

Figure 1. Crystal structures of silver vanadium oxide and silver vanadium phosphorous oxide layered materials: (a) $\mathrm{Ag}_{2} \mathrm{~V}_{4} \mathrm{O}_{11}{ }^{11}{ }^{11}$ (b) $\mathrm{Ag}_{2} \mathrm{VO}_{2} \mathrm{PO}_{4},{ }^{32}$ (c) $\mathrm{Ag}_{0.48} \mathrm{VOPO}_{4},{ }^{33}$ (d) $\mathrm{Ag}_{2} \mathrm{VP}_{2} \mathrm{O}_{8}{ }^{34}$ 
a)

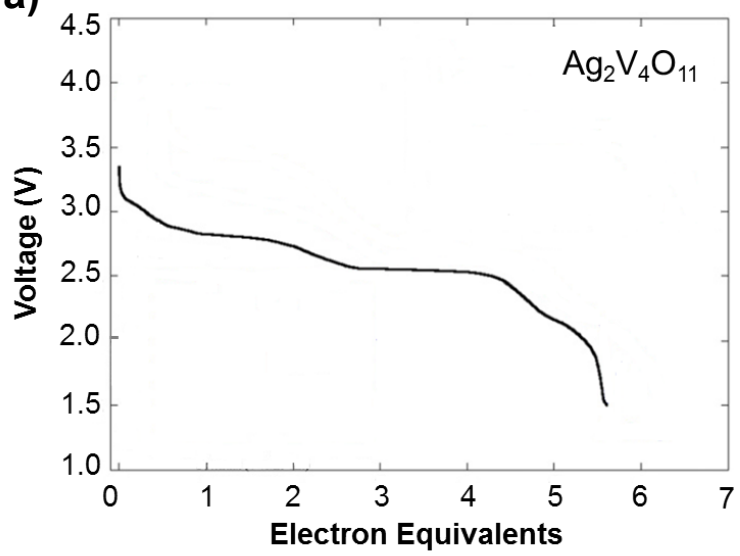

c)

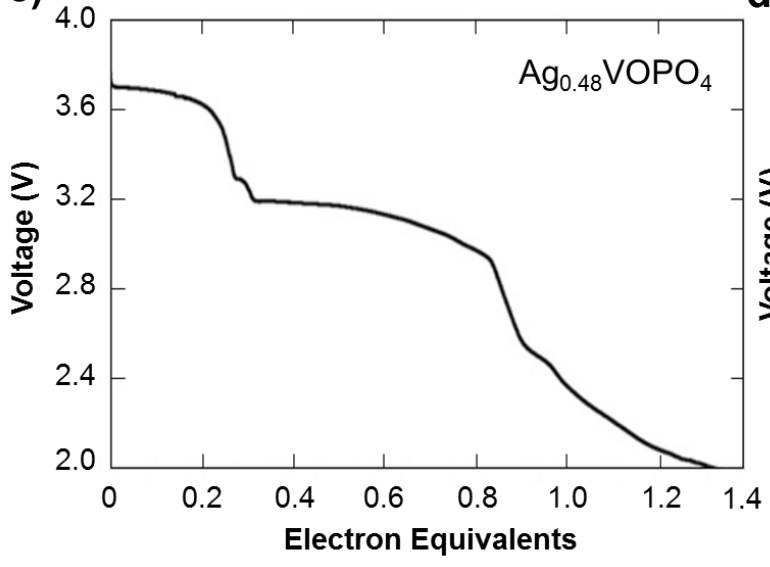

b)

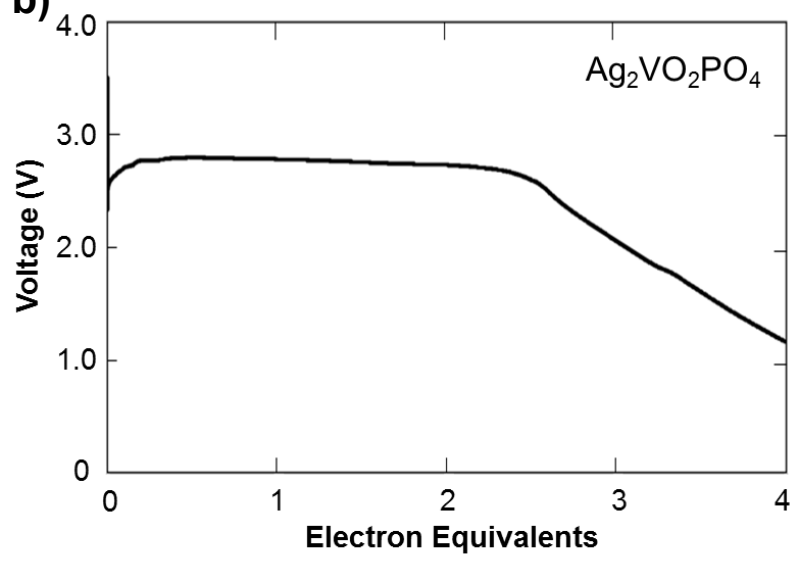

d)

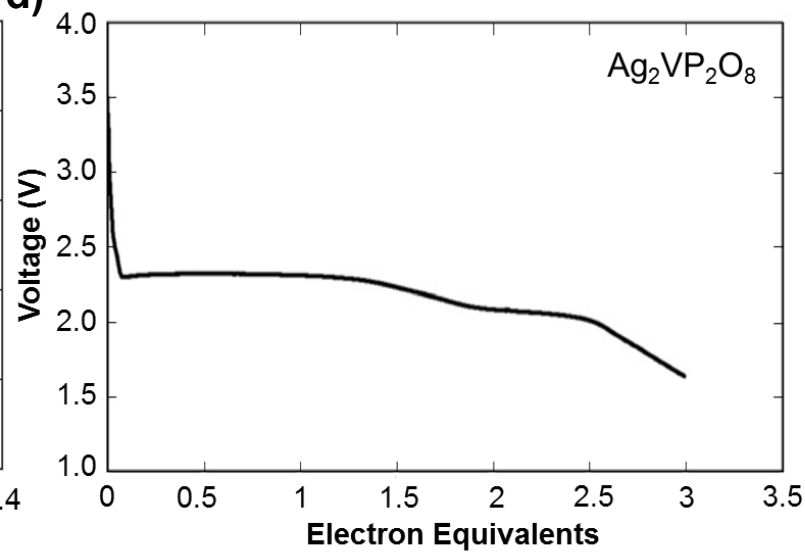

Figure 2. Galvanostatic discharge profiles of (a) $\mathrm{Li} / \mathrm{Ag}_{2} \mathrm{~V}_{4} \mathrm{O}_{11},{ }^{39}$ (b) $\mathrm{Li} / \mathrm{Ag}_{2} \mathrm{VO}_{2} \mathrm{PO}_{4}{ }^{43}$ c) $\mathrm{Li} / \mathrm{Ag}_{0.48} \mathrm{VOPO}_{4},{ }^{42}$ and (d) $\mathrm{Li} / \mathrm{Ag}_{2} \mathrm{VP}_{2} \mathrm{O}_{8}{ }^{37}$ plotted with respect to electron equivalents. Graphs a, c, and d adapted with permission from Ref. 39, 42, and 37, copyright 2016 Elsevier. Graph (b) adapted and reproduced from Ref. 43 by permission of The Royal Society of Chemistry. 


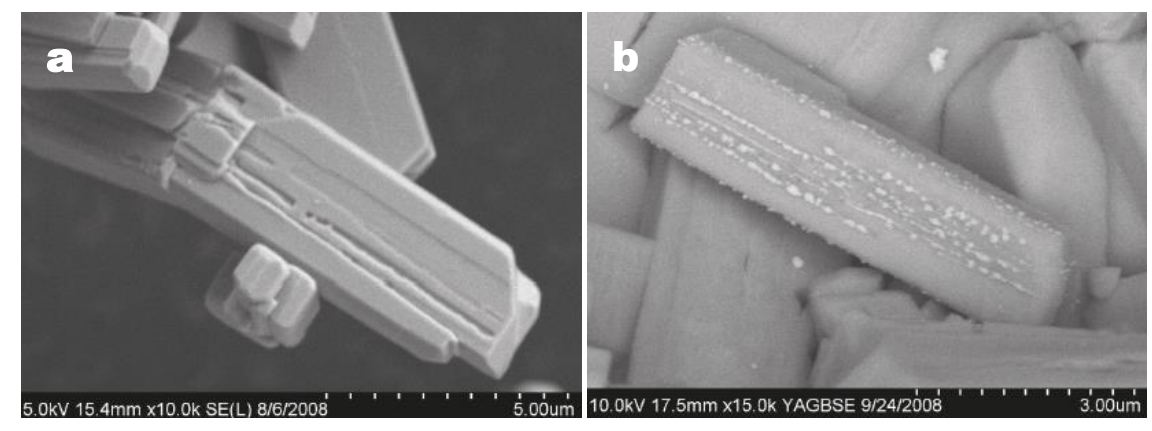

Figure 3. Scanning electron microscopy (SEM) images of (a) pristine $\mathrm{Ag}_{2} \mathrm{VO}_{2} \mathrm{PO}_{4}$ and (b) $\mathrm{Ag}_{2} \mathrm{VO}_{2} \mathrm{PO}_{4}$ discharged (lithiated) to 0.8 molar electron equivalents with $\mathrm{Ag}^{0}$ nanoparticles discernible on the surface of the particle. ${ }^{16}$ Images adapted with permission from Ref. 16. Copyright 2016 American Chemical Society. 
Table 1. Discharge mechanisms and theoretical capacities of silver vanadium oxide and silver vanadium phosphorous oxide materials.

\begin{tabular}{|c|c|c|c|}
\hline Material & \multicolumn{2}{|l|}{ Lithiation Mechanism } & $\begin{array}{c}\text { Theoretical } \\
\text { Capacity }(\mathrm{mAh} / \mathrm{g})\end{array}$ \\
\hline $\mathbf{A g}_{10,39-41} \mathbf{V}_{4}^{\mathbf{V}} \mathbf{O}_{11}$ & $\begin{array}{l}\mathrm{Ag}_{2} \mathrm{~V}_{4}^{\mathrm{V}} \mathrm{O}_{11}+x \mathrm{Li}^{+}+x \mathrm{e}^{-} \rightarrow \mathrm{Li}_{x} \mathrm{Ag}_{2} \mathrm{~V}^{\mathrm{IV}}{ }_{x} \mathrm{~V}_{4-x}^{\mathrm{V}} \mathrm{O}_{11} \\
\mathrm{Li}_{0.7} \mathrm{Ag}_{2} \mathrm{~V}^{\mathrm{IV}}{ }_{x} \mathrm{~V}_{4-x}^{\mathrm{V}} \mathrm{O}_{11}+y \mathrm{Li}^{+}+y \mathrm{e}^{-} \rightarrow \mathrm{Li}_{0.7+y} \mathrm{Ag}_{2-m} \mathrm{~V}^{\mathrm{IV}}{ }_{x+n} \mathrm{~V}_{4-x-n}^{\mathrm{V}} \mathrm{O}_{11}+m \\
\mathrm{Ag}^{0} \\
\mathrm{Li}_{5.5} \mathrm{Ag}_{2-m} \mathrm{~V}^{\mathrm{IV}}{ }_{x+n} \mathrm{~V}_{4-x-n}^{\mathrm{V}} \mathrm{O}_{11}+z \mathrm{Li}^{+}+z \mathrm{e}^{-} \rightarrow \mathrm{Li}_{5.5+z} \mathrm{Ag}_{2-m} \mathrm{~V}_{\varepsilon}{ }_{\varepsilon} \mathrm{V}^{\mathrm{IV}}{ }_{x+n+z} \mathrm{O}_{11} \\
(m \sim 2)\end{array}$ & $\begin{array}{c}x \leq 0.7 \\
0.7 \leq y \leq 5.5 \\
(y=m+n) \\
z \leq 4.5 \\
\varepsilon=\text { trace }\end{array}$ & $\begin{array}{c}450 \\
\left(10 e^{-} \text {equiv. }\right)\end{array}$ \\
\hline$\underset{16,18,37,47}{\mathbf{A g}} \mathbf{V O}_{\mathbf{2}} \mathbf{P O}_{4}$ & $\begin{array}{l}\mathrm{Ag}_{2} \mathrm{~V}^{\mathrm{V}} \mathrm{O}_{2} \mathrm{PO}_{4}+x \mathrm{Li}^{+}+x \mathrm{e}^{-} \rightarrow \mathrm{Li}_{x} \mathrm{Ag}_{2-m} \mathrm{~V}_{n}^{\mathrm{IV}} \mathrm{V}^{\mathrm{V}}{ }_{1-n} \mathrm{O}_{2} \mathrm{PO}_{4}+m \mathrm{Ag}^{0}(m>> \\
\mathrm{Li}_{2} \mathrm{Ag}_{2-m} \mathrm{~V}_{n}^{\mathrm{IV}} \mathrm{V}_{1-n}^{\mathrm{V}} \mathrm{O}_{2} \mathrm{PO}_{4}+y \mathrm{Li}^{+}+y \mathrm{e}^{-} \rightarrow \mathrm{Li}_{2+y} \mathrm{~V}_{m}^{\prime \prime \prime}{ }_{m} \mathrm{~V}_{n}{ }_{n} \mathrm{~V}_{1-2-m-n}^{\mathrm{V}} \mathrm{O}_{2} \mathrm{PO}_{4}\end{array}$ & $\begin{array}{c}x \leq 2 \\
(x=m+n) \\
y \leq 2 \\
(y=m+n) \\
\varepsilon=\text { trace }\end{array}$ & $\begin{array}{c}270 \\
\left(4 e^{-} \text {equiv. }\right)\end{array}$ \\
\hline $\mathrm{Ag}_{0.48} \mathrm{VOPO}_{19,42}$ & $\begin{array}{l}\mathrm{Ag}_{0.48} \mathrm{~V}_{0.48}^{\mathrm{IV}} \mathrm{V}_{0.52}^{\mathrm{V}} \mathrm{OPO}_{4}+x \mathrm{Li}^{+}+x \mathrm{e}^{-} \rightarrow \mathrm{Li}_{x} \mathrm{Ag}_{0.48} \mathrm{~V}_{0.48+x}^{\mathrm{IV}} \mathrm{V}_{0.52-x} \mathrm{OPO}_{4} \\
\mathrm{Li}_{0.52} \mathrm{Ag}_{0.48} \mathrm{~V}^{\mathrm{IV}} \mathrm{OPO}_{4}+y \mathrm{Li}^{+}+y \mathrm{e}^{-} \rightarrow \mathrm{Li}_{0.52+y} \mathrm{Ag}_{0.48-y} \mathrm{~V}^{\mathrm{IV}} \mathrm{OPO}_{4}+y \mathrm{Ag}^{0} \\
\mathrm{LiV}^{\mathrm{IV}} \mathrm{OPO}_{4}+z \mathrm{Li}^{+}+z \mathrm{e}^{-} \rightarrow \mathrm{Li}_{1+z} \mathrm{~V}^{\mathrm{III}} \mathrm{V}^{\mathrm{IV}}{ }_{1-z} \mathrm{OPO}_{4}\end{array}$ & $\begin{array}{l}x \leq 0.52 \\
y \leq 0.48 \\
z \leq 0.26\end{array}$ & $\begin{array}{c}310 \\
\left(2.48 \mathrm{e}^{-} \text {equiv. }\right)\end{array}$ \\
\hline$\underset{37,48,51}{\mathbf{A g}_{\mathbf{2}} \mathbf{V P}_{\mathbf{2}} \mathbf{O}_{\mathbf{8}}}$ & $\begin{array}{l}\mathrm{Ag}_{2} \mathrm{~V}^{\mathrm{IV}} \mathrm{P}_{2} \mathrm{O}_{8}+x \mathrm{Li}^{+}+x \mathrm{e}^{-} \rightarrow \mathrm{Li}_{x} \mathrm{Ag}_{2-m} \mathrm{~V}^{\prime \prime \prime}{ }_{n} \mathrm{~V}^{\mathrm{IV}}{ }_{1-n} \mathrm{P}_{2} \mathrm{O}_{8}+m \mathrm{Ag}^{0} \\
\mathrm{Li}_{2} \mathrm{Ag}_{2-m} \mathrm{~V}_{n}{ }_{n} \mathrm{~V}^{\mathrm{IV}}{ }_{1-n} \mathrm{P}_{2} \mathrm{O}_{8}+y \mathrm{Li}^{+}+y \mathrm{e}^{-} \rightarrow \mathrm{Li}_{2+y} \mathrm{~V}_{n}{ }_{n}{ }^{\prime \prime} \mathrm{V}^{\mathrm{IV}}{ }_{1-n} \mathrm{P}_{2} \mathrm{O}_{8}+y \mathrm{Ag}^{0}\end{array}$ & $\begin{array}{c}x \leq 2 \\
(x=m+n) \\
2 \leq y \leq 3\end{array}$ & $\begin{array}{c}176 \\
\left(3 e^{-} \text {equiv. }\right)\end{array}$ \\
\hline
\end{tabular}


a)
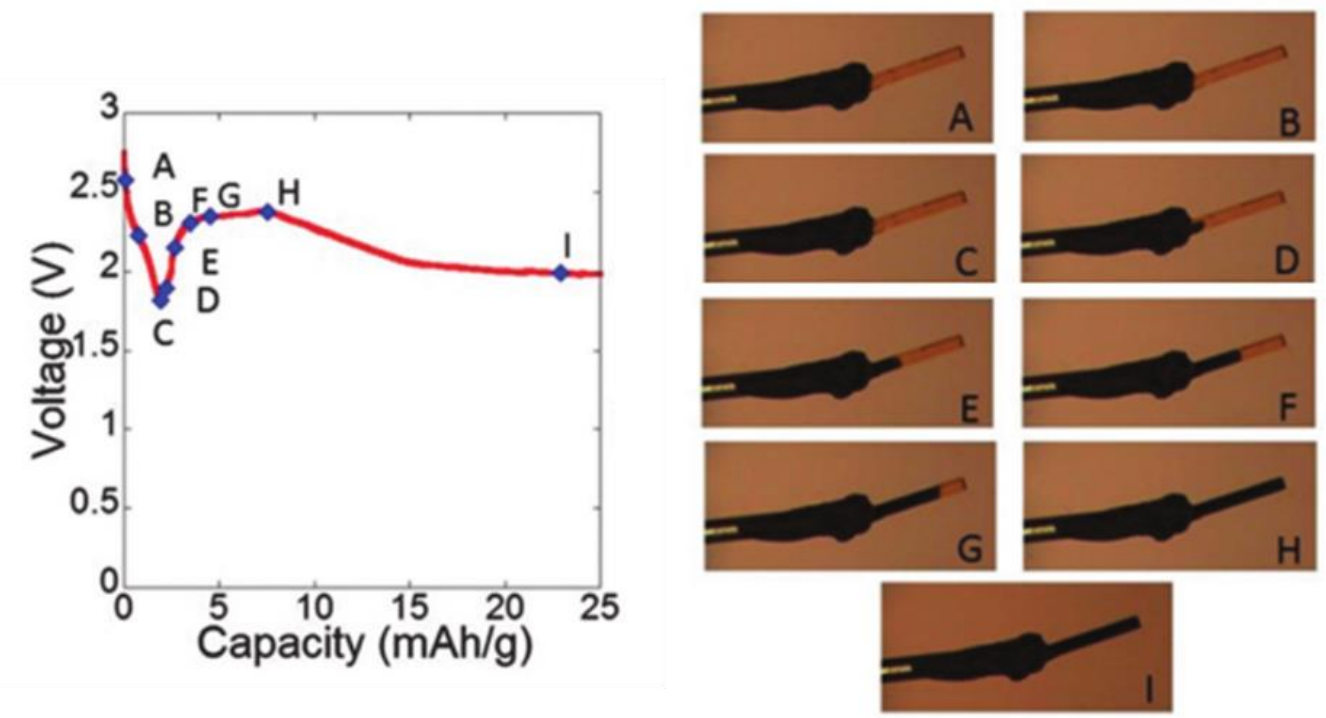

b)
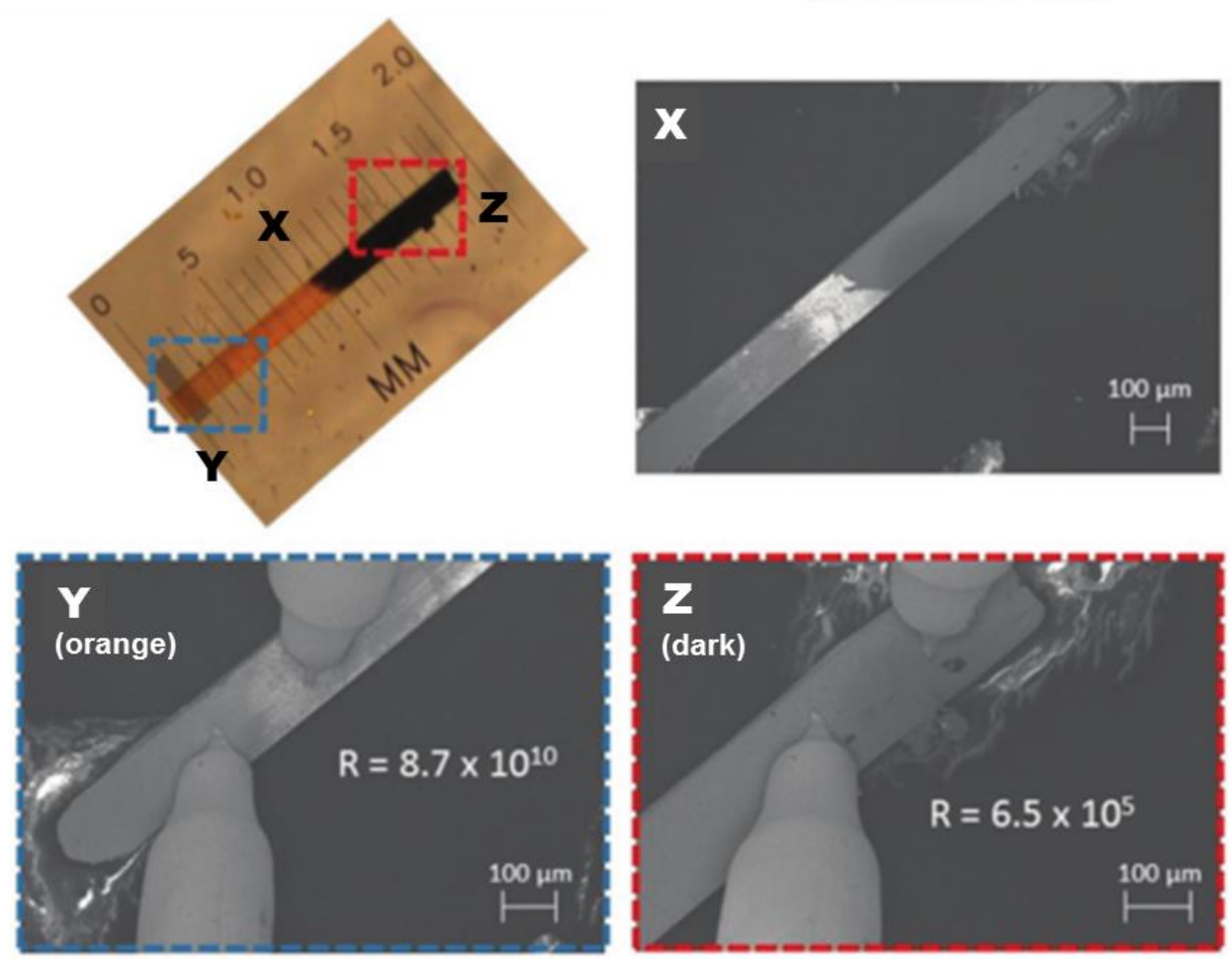

Figure 4. (a) Constant current discharge of an individual $\mathrm{Ag}_{2} \mathrm{VO}_{2} \mathrm{PO}_{4}$ particle. Blue diamonds in the voltage profile correspond to the optical images (shown at right) taken during discharge. (b) Optical and SEM images of a partially discharged $\mathrm{Ag}_{2} \mathrm{VO}_{2} \mathrm{PO}_{4}$ particle. Images $(Y)$ and $(Z)$ illustrate the placement of STM tips for resistance measurements of the orange and dark regions of the particle $(X)$, respectively. ${ }^{51}$ Reproduced from Ref. 51 by permission of The Royal Society of Chemistry. 
a)

b)

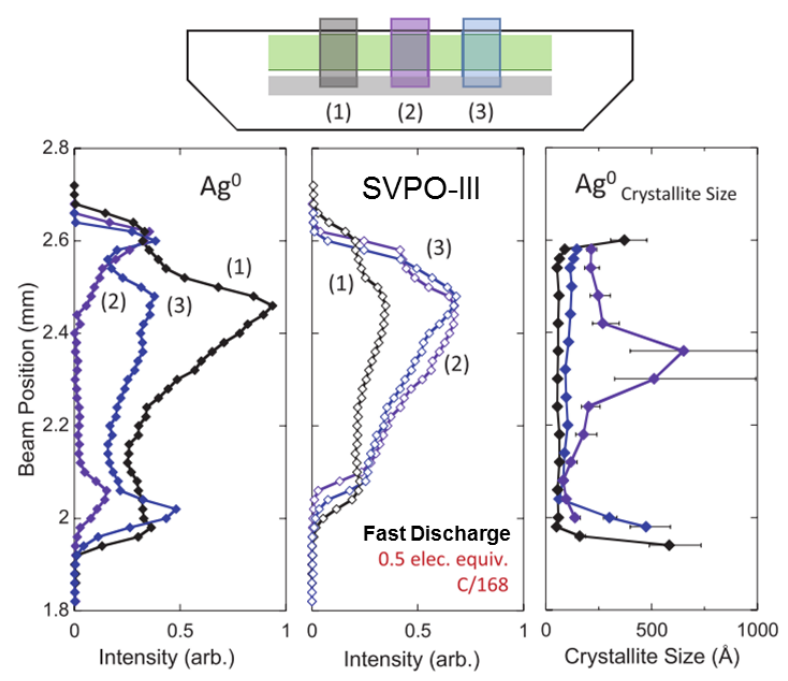

c)

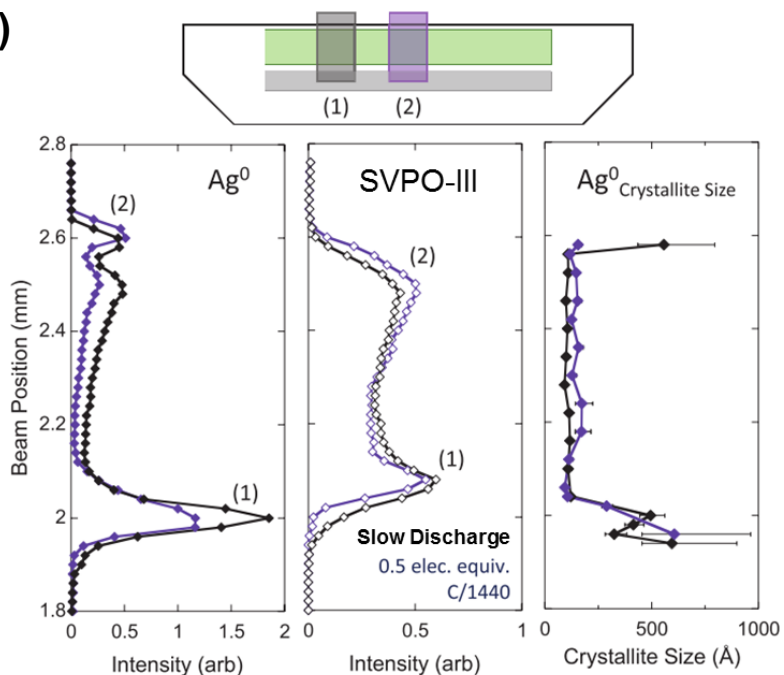

Figure 5. (a) Experimental configuration used for in-situ energy dispersive X-ray diffraction (EDXRD) measurements of $\mathrm{Li} / \mathrm{Ag}_{2} \mathrm{VP}_{2} \mathrm{O}_{8}$ coin cells. (b,c) Intensities of $\mathrm{Ag}^{0}$ and $\mathrm{Ag}_{2} \mathrm{VP}_{2} \mathrm{O}_{8}$ and crystallite size of $\mathrm{Ag}^{0}$ displayed as a function of beam position along the $z$ direction for cathodes discharged to 0.5 electron equivalents with discharge rates of: (b) C/168 (fast) and (c) C/1440 (slow). Separate locations were measured for fast and slow discharge rates, respectively. ${ }^{48,50}$ Image (a) reproduced from Ref. 48 with permission from the PCCP Owner Societies. Images (b) and (c) reproduced from Ref. 50 and reprinted with permission from AAAS. 
a)

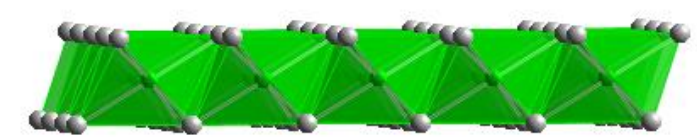

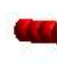

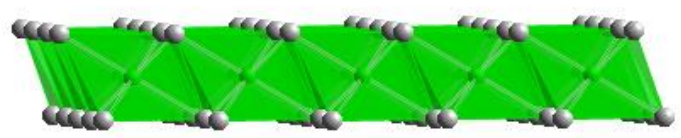

-

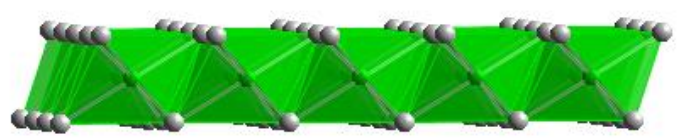

$2 \mathrm{H}-\mathrm{AgFeO}_{2}$ b)
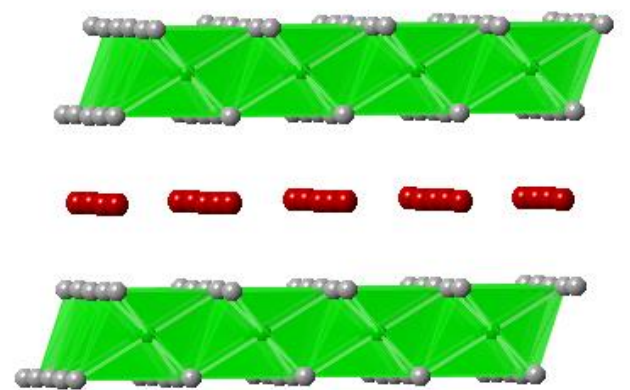

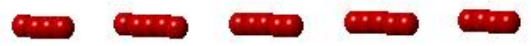

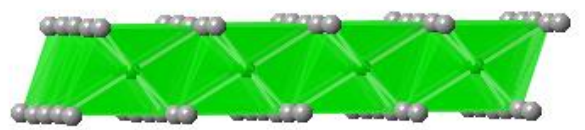

$3 \mathrm{R}-\mathrm{AgFeO}_{2}$

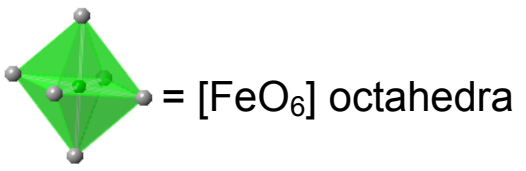

c)

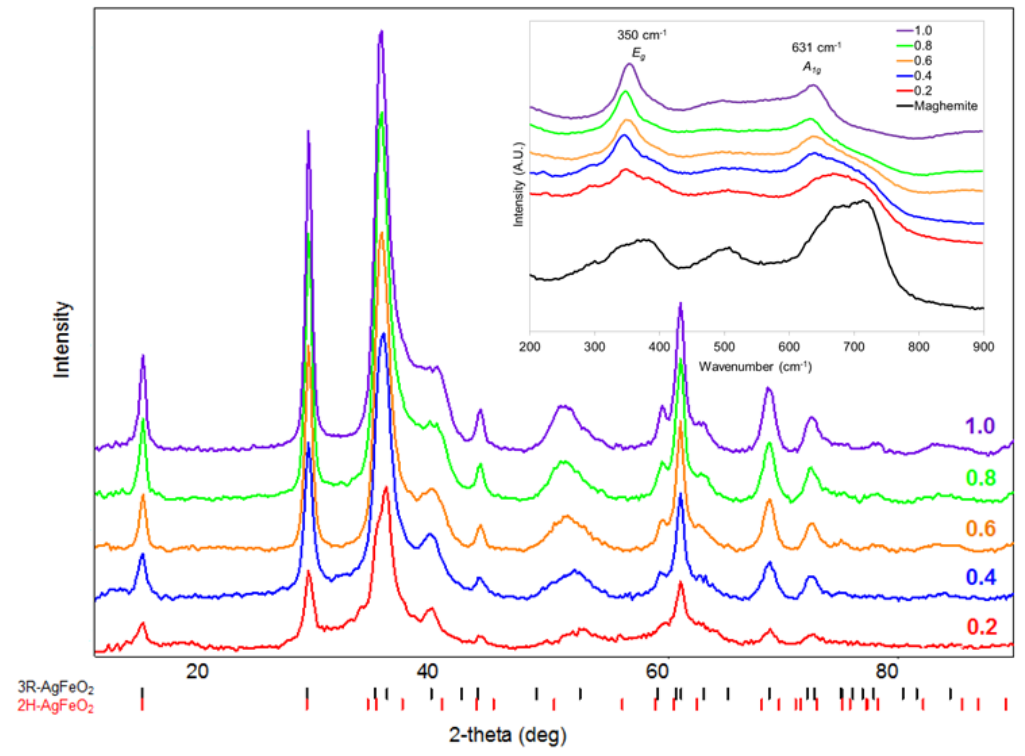

d)

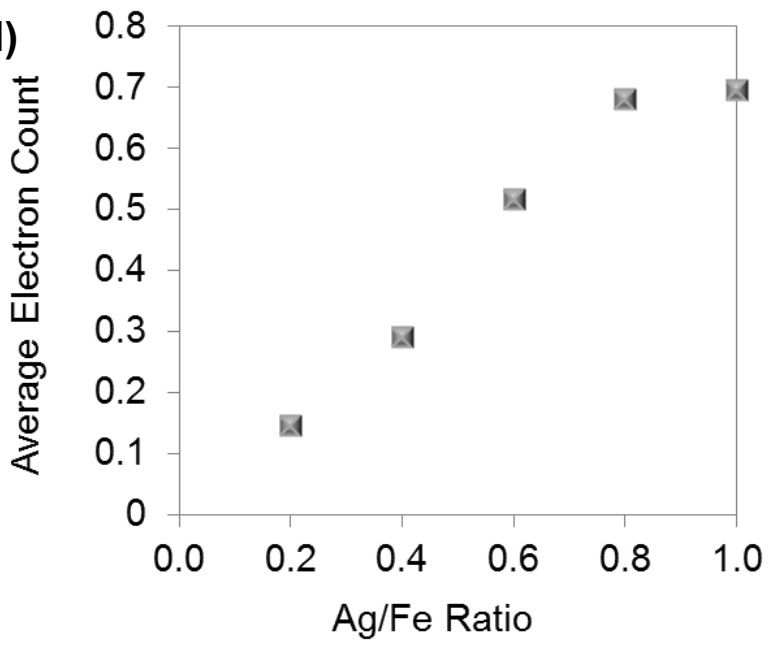

Figure 6. Structures of silver ferrite: (a) $2 \mathrm{H}-\mathrm{AgFeO}_{2}{ }^{53}$ and (b) $3 \mathrm{R}-\mathrm{AgFeO}{ }_{2} \cdot{ }^{54}$ (c) X-ray diffraction (XRD) and Raman spectroscopy of silver ferrite composites as-prepared. (d) Plot demonstrating capacity loss from cycle 1 to cycle 2 as a function of electron count. ${ }^{56}$ Graphs (c) and (d) adapted and reproduced from Ref. 56 by permission of The Royal Society of Chemistry. 